University of Nebraska - Lincoln

DigitalCommons@University of Nebraska - Lincoln

USDA National Wildlife Research Center - Staff Publications
U.S. Department of Agriculture: Animal and Plant Health Inspection Service

1997

\title{
Comparison of Three Formulations of Alphachloralose For Immobilization of Canada Geese
}

Jerrold L. Belant

National Wildlife Research Center

Thomas W. Seamans

USDA/APHIS/WS National Wildlife Research Center, thomas.w.seamans@aphis.usda.gov

Follow this and additional works at: https://digitalcommons.unl.edu/icwdm_usdanwrc

Part of the Environmental Sciences Commons

Belant, Jerrold L. and Seamans, Thomas W., "Comparison of Three Formulations of Alphachloralose For Immobilization of Canada Geese" (1997). USDA National Wildlife Research Center - Staff Publications. 1027.

https://digitalcommons.unl.edu/icwdm_usdanwrc/1027

This Article is brought to you for free and open access by the U.S. Department of Agriculture: Animal and Plant Health Inspection Service at DigitalCommons@University of Nebraska - Lincoln. It has been accepted for inclusion in USDA National Wildlife Research Center - Staff Publications by an authorized administrator of DigitalCommons@University of Nebraska - Lincoln. 


\title{
COMPARISON OF THREE FORMULATIONS OF ALPHA- CHLORALOSE FOR IMMOBILIZATION OF CANADA GEESE
}

\author{
Jerrold L. Belant ${ }^{1.2}$ and Thomas W. Seamans' \\ 'U.S. Department of Agriculture, National Wildlife Research Center, 6100 Columbus Avenue, Sandusky, Ohio 44870, \\ USA \\ 2Present address: National Park Service, Denali National Park, P.O. Box 9, Denali NP\&P, Alaska 99755, USA
}

ABSTRACT: The effectiveness of an alpha-chloralose (AC)-com oil suspension, an AC-margarine mixture, and AC tablets were compared for immobilizing Canada geese (Branta canadensis). Responses to AC immobilization also were compared in male and female Canada geese. There was no difference in mean time to first effects or mean time to capture between male and female geese dosed with $30 \mathrm{mg} / \mathrm{kg} \mathrm{AC}$ in orally-administered bread baits. Recovery times ( $\leq 24 \mathrm{hr}$ ) also were similar between sexes. Mean $( \pm \mathrm{SE})$ time to first effects for geese immobilized with AC tablets in bread baits ( $19 \pm 3 \mathrm{~min}$ ) was significantly less than mean time to first effects for geese immobilized with AC in margarine $(28 \pm 6 \mathrm{~min})$ or AC in corn oil $(32 \pm 7 \mathrm{~min})$ applied to bread baits $(n=12$ geese/treatment). Respective mean times to capture geese immobilized with AC tablets, AC-margarine, and AC-corn oil were not significantly different at $62 \pm 25,89 \pm 48$, and $88 \pm 30 \mathrm{~min}$, respectively. Ten, 11 and, seven geese immobilized with AC tablets, AC-margarine, and AC-corn oil recovered within $24 \mathrm{hr}$, respectively; all geese recovered within $28 \mathrm{hr}$. Male and female Canada geese respond similarly to $\mathrm{AC}$ immobilization, at least during molt, and $\mathrm{AC}$ mixed with margarine or AC in tablet form is at least as effective as the presently used AC-corn oil suspension. AC tablets or AC-margarine also would be more practical for some field situations. Additional development of $\mathrm{AC}$ tablets will be required prior to field use for capturing nuisance waterfowl.

Key words: Alpha-chloralose, Branta canadensis, Canada goose, formulation, immobilization, laboratory study, tablet.

\section{INTRODUCTION}

Alpha-chloralose (AC) is a chloral derivative of glucose which depresses the cortical centers of the brain but does not effect the medula (Borg, 1955; Crider and McDaniel, 1967). AC has been used as an anesthetic in laboratory animals since 1897 (Balis and Monroe, 1964). AC also has been used to capture numerous avian species including wild turkeys (Meleagris gallopavo) (Williams, 1966); marabou storks (Leptotilos crumeniferus) (Pomeroy and Woodford, 1976); American crows (Corvus brachyrhynchos) (Stouffer and Caccamise, 1991); and waterfowl, American coots (Fulica americana), and pigeons (Columba livia) (Woronecki et al., 1992; Woronecki and Dolbeer, 1994).

Although AC has been used extensively as an avian capture agent, it was not registered for use to live-capture animals in the United States. However, after conducting laboratory and field trials, the U.S.
Department of Agriculture's Animal Damage Control (ADC; Washington D.C., USA) program received approval from the U.S. Food and Drug Administration (Washington D.C., USA) in 1992 to use AC to capture nuisance waterfowl, pigeons and coots (Woronecki et al., 1990; 1992; Woronecki and Dolbeer, 1994). Presently, AC is available for use in the United States only by trained ADC personnel or their designees. During 1994 and 1995, ADC personnel used AC to capture 4,000 waterfowl, coots, or pigeons in nuisance situations in the United States.

The technique generally used to capture nuisance waterfowl is to put $A C$ in suspension in corn oil, inject by syringe individual bread baits with predetermined amounts of the suspension and hand-toss the treated baits to target individuals (Woronecki et al., 1992). Although this procedure is effective, it is inefficient for conducting large-scale capture of nuisance 
waterfowl. We have received requests from ADC personnel to develop more practical formulations of $\mathrm{AC}$ for field use that do not involve the use of syringes. Additionally, previous work has suggested that male and female Canada geese may respond differently to similar dose rates of AC (Woronecki et al., 1992). Thus, our objectives were to (1) determine if male and female Canada geese respond similarly to AC immobilization and (2) compare the effectiveness of AC formulated with corn oil, margarine or as a tablet for immobilization of Canada geese.

\section{MATERIALS AND METHODS}

This study was conducted from June to September 1996. Adult-plumaged Canada geese were captured during molt in northern Ohio and transported to the National Aeronautic and Space Administration's (NASA) Plum Brook Station (Erie County, Ohio; $41^{\circ} 20^{\prime} \mathrm{N}, 82^{\circ} 40^{\prime} \mathrm{W}$ ). Geese were placed in a 2-ha fenced area containing a pond with grass and shade along the shore and maintained as described by Belant et al. (1996). Geese were herded from the pond 2 to 4 days before each experiment, individually marked with leg bands or neck collars, and placed in $2.4 \times 2.4 \times 2.0 \mathrm{~m}$ holding cages ( 3 to 4 geese/cage). In addition to grass, geese in the cages were provided corn, water, and shade. Experimentally-näve geese were used in each experiment; all geese were released after the experiments were completed.

We obtained vials containing $2.04 \mathrm{~g} \mathrm{AC}$ from the Pocatello Supply Depot (Pocatello, Idaho, USA). The AC contained $86.9 \%$ of the alpha isomer (S. Blom, Pocatello Supply Depot, unpubl. data).

On 1 July 1996, 24 geese ( 8 males, 16 females) were dosed using orally-administered AC-treated bread. Bread baits (2 to $3 \mathrm{~cm}^{2}$ ) were prepared from slices of fresh white bread with crusts removed. We prepared $16.25 \mathrm{ml}$ of suspension by mixing $2.04 \mathrm{~g}$ AC with $15 \mathrm{ml}$ corn oil. Using a 1-cc syringe, each bread bait was injected with a calculated volume of suspension such that each goose received $30 \mathrm{mg}$ $\mathrm{AC} / \mathrm{kg}$ body mass (see Woronecki et al., 1992). After dosing, geese were returned to the holding cages for observation.

Time to first effects was recorded as the interval $(\mathrm{min})$ from bait administration to observations of AC-induced behavior (e.g., unnatural posture, slowly blinking eyes, relaxed wings, and poor motor abilities). Time to capture was recorded as the interval from bait administra- tion to when geese appeared susceptible to capture by hand or with hand-held net (see Woronecki et al. 1992). Time to recovery was the interval from time to capture to when geese appeared able to escape capture by hand (see Crider and McDaniel, 1967; Martin, 1967; Woronecki et al., 1992). Geese were observed continuously until all were considered capturable. Geese then were monitored at $1 \mathrm{hr}$ intervals until $1600 \mathrm{hr}$ and the following day beginning at $0600 \mathrm{hr}$ until all geese had recovered. Thus, time to recovery was not known for many of the geese as they were not observed for a 14 $\mathrm{hr}$ period. We used independent $t$-tests (Zar, 1984) to compare mean body mass, mean time to first effects, and mean time to capture between male and female geese.

Each of three groups of 12 geese was treated with a different $\mathrm{AC}$ formulation (AC tablet, AC-margarine mixture or AC-corn oil suspension). To simulate field use, the mean body mass for each group treated with a given formulation was predetermined and used to calculate the mean most effective dose $(30 \mathrm{mg} / \mathrm{kg}$ ) for each group.

The AC-corn oil suspension was made as described previously and injected into bread baits. The AC-margarine mixture was prepared by combining 4 teaspoons of margarine (containing 70\% vegetable oil) with $1.68 \mathrm{~g} \mathrm{AC}$ and hand-mixing the ingredients for about $1 \mathrm{~min}$. A quarter teaspoon of the mixture was then placed on each bread bait prior to administration.

To make AC tablets, we drilled $12.5 \mathrm{~mm}$ diameter holes into a $8 \mathrm{~mm}$ thick piece of aluminum. We then secured an additional metal plate to the aluminum. AC was exposed to air for $10 \mathrm{~min}$ to absorb atmospheric moisture. We then filled each of the 12 holes with AC and allowed moisture absorption to occur for about another $15 \mathrm{~min}$. Using a 5-mm diameter steel rod, we manually compressed the AC in each hole. The bottom plate was then removed and the AC tablets were pushed through the holes using the steel rod. We weighed each tablet, and using a scalpel, adjusted the mass of each tablet to the mean body mass of the 12 experimental geese. Each tablet was then placed in a bread bait, and the bread was compressed around the tablet before administration.

We administered bread baits with the ACcorn oil suspension and AC-margarine mixture on 28 August 1996; AC tablets were administered on 26 September 1996. Geese were handled and observed as described in the previous experiment. We used single-factor analysis of variance (Zar, 1984) to compare mean body mass, mean dosage of $\mathrm{AC}$, mean time to first effects, and mean time to capture among 
TABLE 1. Dosages, body mass and responses of Canada geese immobilized with alpha-chloralose (AC) in tablets, margarine, or corn oil in orally-administered bread baits (12 geese/treatment), July to September 1996, Ohio (USA).

\begin{tabular}{|c|c|c|c|c|c|c|c|c|c|}
\hline \multirow[b]{2}{*}{ Parameter } & \multicolumn{3}{|c|}{ AC: tablets } & \multicolumn{3}{|c|}{ AC: margarine } & \multicolumn{3}{|c|}{ AC com oil } \\
\hline & Mean: & $\mathrm{SE}$ & Range & Mean ${ }^{a}$ & SE & Range & Mean: & SE & Range \\
\hline AC: $(\mathrm{mg} / \mathrm{kg})^{\mathrm{h}}$ & $30.5 \mathrm{~A}$ & 1.1 & $23.5-36.4$ & $31.1 \mathrm{~A}$ & 1.3 & $24.1-38.2$ & $30.1 \mathrm{~A}$ & 1.0 & $24.5-36.0$ \\
\hline Body mass $(\mathrm{kg})^{c}$ & $4.1 \mathrm{~B}$ & 0.2 & $3.4-5.2$ & $3.5 \mathrm{~A}$ & 0.2 & $2.8-4.4$ & $3.6 \mathrm{~A}$ & 0.1 & $3.0-4.4$ \\
\hline Time to first effects $(\min )^{d}$ & $19 A$ & 1 & $15-24$ & $28 B$ & 2 & $18-36$ & $32 \mathrm{~B}$ & 2 & $21-42$ \\
\hline Time to capture $(\min )^{e}$ & $62 \mathrm{~A}$ & 7 & $27-128$ & $89 \mathrm{~A}$ & 14 & $47-224$ & $88 \mathrm{~A}$ & 9 & $55-156$ \\
\hline Number recovered in $24 \mathrm{hrs}$ & 9 & & & 10 & & & 6 & & \\
\hline
\end{tabular}

a Means in a row with the same letter are not different.

${ }^{b} F=0.17 ; 2.33 \mathrm{df} ; P=0.84$

c $F=4.80 ; 2,33 \mathrm{df} ; P=0.01$

d $F=16.15 ; 2.33$ df: $P<0.01$

C $F=2.16 ; 2.33$ df: $P=0.13$.

${ }^{f}$ All geese recovered in $28 \mathrm{hr}$

groups of geese receiving each of the three formulations. If significant differences $(P<0.05)$ were detected, we used Tukey tests to determine which means differed.

\section{RESULTS}

Mean $( \pm \mathrm{SE})$ body mass of male $(4.4 \pm$ $0.2 \mathrm{~kg})$ and female $(4.3 \pm 0.1 \mathrm{~kg})$ geese was similar $(t=0.65,22 \mathrm{df}, P=0.52)$. Time to first effects also was similar $(t=$ $1.54,22 \mathrm{df}, P=0.14)$ for male $(20.5 \pm 2.3$ $\mathrm{min})$ and female $(16.7 \pm 1.3 \mathrm{~min})$ geese. There was no difference $(t=0.02,22 \mathrm{df}$, $P=0.99)$ in time to capture for male (106 $\pm 10 \mathrm{~min})$ and female $(106 \pm 9 \mathrm{~min})$ geese. All geese recovered in $\leq 24 \mathrm{hr}$.

Mean body mass of geese receiving ACtablets was greater $(P<0.05)$ than mean body mass of geese receiving AC-margarine; however, mean dosages among groups were similar $(P=0.84$, Table 1$)$. Time to first effects was less $(P<0.05)$ for geese receiving $\mathrm{AC}$-tablets than for geese receiving AC-oil or AC-margarine. Although the mean time to capture geese treated with AC-tablets was $\geq 31 \%$ less than the mean time to capture geese treated with the other AC formulations, this difference was not significant $(P=0.13)$. Seven geese recovered within $24 \mathrm{hr}$ from the AC-corn oil suspension in contrast to 10 and 11 geese immobilized with AC tablets and AC-margarine, respectively. All geese recovered within $28 \mathrm{hr}$.

\section{DISCUSSION}

In contrast to Woronecki et al. (1992), we did not find differential responses of male and female Canada geese to AC immobilization. Woronecki et al. (1992) reported mean times to capture of 54 and 102 min for male $(n=4)$ and female $(n$ $=6$ ) geese, respectively. We are uncertain of the disparity between studies in mean times to capture for male geese; procedures used to administer AC were similar in each study. The disparity could be an artifact of sample size, time of year geese were immobilized, differences in physical condition, individual variation in geese or a combination of these factors. Nonetheless, male and female Canada geese responded similarly to AC immobilization in our study, at least during molt.

Overall, AC-margarine and AC tablets were at least as effective as AC-corn oil for immobilizing Canada geese when applied to bread baits administered orally. Because geese responded similarly to immobilization using bread baits treated with an ACcorn oil suspension during laboratory and field trials (Woronecki et al. 1992), we believe that individuals conducting field trials using AC-margarine or AC tablets will obtain results comparable to our laboratory trials.

In our study, the margarine $(70 \%$ corn oil) liquified when mixed with $\mathrm{AC}$, making 
application of the mixture to bread baits difficult. Cooling the AC-margarine mixture to a temperature equal to or lower than the ambient temperature prior to field use will alleviate this potential problem.

Additional development would be required to improve the durability of $\mathrm{AC}$ tablets. Tablets used in this study were friable and would not be suitable for largescale production. The technology to manufacture AC tablets is presently available in the pharmaceutical industry. For example, lactose or another binding agent may be required and a surface coating would probably be necessary to prevent tablets from fragmenting. Alternatively, commercially-manufactured capsules that dissolve rapidly after ingestion may be suitable for delivering AC. Development of a standardized AC concentration(s) also would be necessary. For example, tablets could be made to contain $32 \mathrm{mg} \mathrm{AC}$ and designed such that they could be separated into 2 equal pieces. Using typical body mass and the most effective dose of $\mathrm{AC}$ (30 $\mathrm{mg} / \mathrm{kg}$ ) for waterfowl, coots or gulls (Woronecki et al., 1992; J. Belant, unpubl. data), a half tablet, single tablet, or a multiple of tablets containing $32 \mathrm{mg} \mathrm{AC}$ could be used successfully for field immobilization of these species.

The AC-margarine mixture and AC tablets could have considerable field application for immobilizing nuisance waterfowl and other birds. AC-margarine was as effective as AC-corn oil and is easier to use. If development is completed, AC tablets (or capsules) could provide even greater ease of use, with less equipment and no mixing of materials required. We do not recommend discontinuing use of AC-corn oil because it is effective when injected into bread baits and also it is used occasionally as a surface coating on corn to capture nuisance waterfowl, coots and pigeons (Woronecki et al. 1992). Rather, we recommend having all three formulations available to maximize the ability of ADC personnel to resolve nuisance wildlife problems.

\section{ACKNOWLEDGMENTS}

J. L. Cummings provided the initial idea for formulating $\mathrm{AC}$ into tablets; $\mathrm{L}$. Clark provided background information on tablet formulation. We thank C. R. Bartholomew, R. A. Dolbeer, S. K. Ickes, C. D. Lovell, R. G. McLean, L. A. Tyson, and S. E. Wright for assistance. Canada geese were provided by A. J. Montoney (ADC) and Ohio Division of Wildlife personnel; A. L. Bower (NASA) provided study sites. Sponsorship and funds for this research was provided by the Federal Aviation Administration (FAA), office of Airport Safety and Standards, Washington, D.C., and Airports Division, Airport Technology Branch, FAA Technical Center, Atlantic City International Airport, New Jersey. We appreciate the support and advice of $\mathrm{T}$. $\mathrm{H}$. Hupf (FAA).

\section{LITERATURE CITED}

Balis, G. U., ANd R. R. MONRoE. 1964. The pharmacology of chloralose. Psychopharmacologia 6: 1-30.

Belant, J. L., T. W. Seamans, L. A. Tyson, ani) $S$. K. ICKES. 1996. Repellency of methyl anthranilate to pre-exposed and naive (anada geese. The Journal of Wildlife Management 60: 923928.

BORG, K. 1955. ('hloralose and its use for catching crows, gulls, pigeons, etc. Viltrewy Jakbiologisk Tidskrift 1: 88-121.

Crider, E. D)., AND J. (. MCDaNiel. 1967. Alphachloralose used to capture Canada geese. The Journal of Wildlife Management 31: 258-264.

Martin, L. L. 1967. Comparison of methoxymol, alpha-chloralose and two barbituates for capturing doves. Proceedings of the Southeast Association of Game and Fish Commissions 21: 19.3201.

POMEROY, D. E., AND M. H. W(OODFORI). 1976. Drug immobilization of marabou storks. The Journal of Wildlife Management 40: 177-179.

STOLFFER, P. C., AND D. F. CACCANISE. 1991. (Capturing American crows using alpha-chloralose. Journal of Field Ornithology 62: 450-453.

Williams, L. E., JR. 1966. Capturing wild turkeys with alpha-chloralose. The Journal of Wildlife Management 30: 50-56.

WORONECKI, P. P., AND R. A. DOLBEER. 1994. Alpha-chloralose: current status, restrictions and future uses for capturing birds. Proceedings of the Vertebrate Pest Conference 16: 25.5-258. 
- - AND T. W. SEamans. 1990. Use of alpha-chloralose to remove waterfowl from nuisance and damage situations. Proceedings of the Vertebrate Pest Conference 14: 343-349.

, AND W. R. LANCE. 1992. Alpha-chloralose efficacy in capturing nuisance waterfowl and pigeons and current status of FDA registration. Proceedings of the Vertebrate Pest Conference 15: 72-78.

ZAR, J. H. 1984. Biostatistical analysis, 2nd ed. Prentice Hall, Englewood Cliffs, New Jersey, 718 pp.

Received for publication 19 November 1996. 